\title{
Withholding of Pension Benefits in South Africa: A Nightmare for Pension Fund Members
}

\author{
Dennis Matotoka
}

Lufuno Nevondwe

Kola O. Odeku

Faculty of management and Law, School of Law University of Limpopo, South Africa

\section{Doi:10.5901/mjss.2014.v5n15p647}

\begin{abstract}
This paper looks at the dynamics of withholding pension benefits in South Africa. It has often been argue that the fund do not have powers to withhold the pension fund and contend that such conduct is unlawful. In the premise the paper will evaluate the right of the employer to claim compensate against the employee through the withholding the pension benefits and the right of the members to their pension benefits. The paper will further determine whether the withholding of pension benefits extends to loss suffered by the employer as a result of employee and employer agreement. Pursuant to this, the principles laid out in the cases shall be evaluated against the backdrops of the challenges and solutions they offered.
\end{abstract}

Keywords: Pension Benefits, Employers, Employees, Fraud, Judicial Interventions

\section{Introduction}

It is generally accepted that when a pension member contributes towards a fund the ultimate objective is to prepare for a life after retirement (Nunoo, 2013). This is of paramount importance hence the Pension Funds Act 24 of 1956 (the Act) provides adequate protection to Pension benefits. However, the Office of the Pension Funds Adjudicator (OPFA) in South Africa receives a number of complaints where pension benefits are withheld by the employers and pension members contend that the employer's conduct to withhold such benefits is not in line with the Act. These complaints before the OPFA confirms that majority of pension members and employers do not fully understand the circumstances in which pension benefits may be withheld and this prompts an in depth research to provide a better interpretation of the Act.

\section{Aims and Objectives of the Study}

The paper critically analyses the current laws, pension fund rules and regulations that regulate the protection of pension benefits in South Africa. The objective of this paper is to determine whether to hold pension benefits is in line with the Act. In achieving this objective, the paper determines firstly the extent in which the fund may withhold the pension benefits of the members and secondly whether the right to withhold pension benefits is absolute.

\section{Methodology}

The research methodology used in this study is qualitative, relying on literature relevant to the study. Pursuant to this, the study relied on library materials such as textbooks, legislations, regulations, case laws and articles.

\section{Legislative Framework}

The Pension Benefits are afforded special protection in the Act in the following respect:

- Section $37 \mathrm{~A}(1)$ of the Act prohibits the reduction, transfer, cession, pledge or hypothecation of pension benefits.

- In terms of section 37B of the Act if a member becomes insolvent, pension benefits are deemed not to form part of the insolvent estate and are thereby protected from erosion by creditors.

- Section $37 \mathrm{C}$ of the Act deems pension benefits payable on the death of a member, subject to certain exceptions, not to form part of the assets of the estate of the deceased member. 
- Section 19 of the Act also serves to protect pension benefits by restricting the manner in which a fund's assets may be invested.

The legislature has, in some instances, lifted the special protection given to pension benefits. Section 37D of the Act is one such example. It permits nine kinds of deductions (Queen, 2013):

- Any amount due on the benefit by the member in terms of the Income Tax Act.

- Any amount due to the fund in respect of a housing loan granted to the member by the fund in terms of section 19(5).

- Any amount due to the fund in respect of any amount for which the fund becomes liable under a guarantee furnished for a housing loan granted to the member by some other person usually a bank or a building society.

- Any amount due by a member to his employer owing on the date of his retirement or termination of membership in respect of a housing loan granted by the employer to the member.

- Any amount due by the member to his employer on the date of his retirement or termination of membership in respect of any amount for which the employer is liable under a guarantee furnished in respect of a housing loan granted by some other person, usually a bank or building society.

- Any amount due by a member to his employer on the date of his retirement or termination of membership in respect of compensation for any damage caused to the employer by reason of any theft, dishonesty, fraud or misconduct by the member.

- Any amount which the fund has paid or will pay by arrangement, and on behalf of, a member or beneficiary in respect of subscriptions to a medical aid scheme.

- Any amount which the fund has paid or will pay by arrangement, and on behalf of, a member or beneficiary in respect of insurance premiums.

- Any amount which the fund has paid or will pay by arrangement, and on behalf of, a member or beneficiary in respect of any purpose approved by the Registrar on the conditions determined by the Registrar upon a request in writing from the fund.

\section{Withholding Pension Benefits: Issues and Challenges}

Generally by the time the fraud, theft or misconduct is detected in the workplace, the employer would have already suffered a considerable loss (Wells, 2011). Although employers are often quick to investigate the circumstances surrounding fraud, theft or misconduct perpetrated against the company, employers tend to be hesitant to initiate civil proceedings against guilty employees out of concern that the employee would not have sufficient assets to satisfy any judgment that is ultimately obtained (Blount, 2010).

According to Malindi (2012) the principal benefit of withholding an employee's pension benefits in terms of section $37 \mathrm{D}(1)(\mathrm{b})$ is that an employer is reasonably assured that there will be an asset against which to execute once judgment is ultimately obtained. Such deductions form the subject matter of many complaints before the Adjudicator and therefore deserve further discussion.

It has become evident before the OPFA that both employees and employers do not have an understanding of when exactly pension benefits may be withheld (Bendix, 2010). In the case of Anstey and Pegasus III Provident Fund PFA/GA/147/98/NJ the issue was whether the employer exercised its discretion properly by indefinitely withholding the complainant's benefit for a period exceeding two years. The Adjudicator observed that where the proceedings are pending, it might be argued that the power of deduction implied an entitlement to withhold the benefit pending final determination. However in this matter there were no proceedings to recover had been instituted, in the premise, the Adjudicator found that the employer exceeded its powers for holding pension benefits for a period exceeding two years and thus ordered it to pay the complainant's benefits.

It is important to note that the power to withhold a benefit can only be derived from a statute or the rules of the fund (Bendix, 2010). A rule would be reasonable if it serves to achieve a legitimate objective (Appanna v Kelvinator Group Services of SA Provident Fund).In Horne and Absa Group Pension Fund [2001] 1 BPLR 1479 (PFA) the adjudicator was tasked to determine, inter alia, whether the rules instructing the employers to withhold payment of the benefit for a period not exceeding 12 months following the date of termination of a member's membership was lawful. The Adjudicator found that the rules where lawful, understandable and reasonable and observed that the said rule was an acceptable and proportional means designed to give the employer adequate time to pursue its remedies to recover its losses. Thus the rules were achieving a legitimate objective.

According to Jeram and Shrosbree (2005) the requirements of section $37 \mathrm{D}(1)(\mathrm{b})(\mathrm{ii})$ are very specific and must be 
strictly adhered to before a deduction will be lawful. Section $37 \mathrm{D}(1)(\mathrm{b})(\mathrm{ii})$ does not expressly permit the withholding of a benefit. However in Appanna v Kelvinator Group Services of SA Provident Fund [2000] 2 BPLR 126 (PFA), the Adjudicator came to the conclusion that in order to give effect to the purpose of section $37 \mathrm{D}(1)(\mathrm{b})(\mathrm{ii})$, namely, to protect an employer's right to pursue recovery of misappropriated monies, section $37 \mathrm{D}(1)(\mathrm{b})(\mathrm{ii})$ must be interpreted impliedly to include the power to withhold payment of the benefit pending the determination of liability. The power to withhold must be exercised reasonably however what constitutes 'reasonable' depends on the circumstances of the case (Buthelezi $v$ Municipal Gratuity Fund \& Another (1) [2001] 5 BPLR 1996 (PFA).

Can the fund withhold the benefits for loss resulting from employer-employee contractual agreement? This was the legal question in the recent 2013 case of PM De Kock v Compass Group Southern Africa Pension Fund PFA/MP/00002506/2013) It was submitted on behalf of the respondent before the Adjudicator that complainant's duties as a project manager involved procuring, managing, securing and proper utilisation of the stock. It was further submitted that the complainant in the execution of his duties amongst others failed or neglected to properly manage, record or accurately account for the stock. As a result of the aforementioned, it was indicated that the respondent suffered loss in the amount of $\mathrm{R} 2726$ 794.25. It was argued that this dishonest concealment constitutes a misconduct in terms of section 37D (1)(b)(ii)(bb) of the Act. A civil suit was instituted in the North Gauteng High Court against the complainant and also criminal charges were laid against the latter. As a result a request to withhold the benefit pending finalisation of the civil claim as well as the criminal case was made.

According to Jeram and Shrosbree (2005) before a deduction is permitted, either the member must have admitted liability to the employer in writing or a judgment must have been obtained against the member. Both the admission and judgment must be for compensation owing to the employer for damage caused to it by the member's dishonest conduct. So for example, a written admission that the member is indebted to the employer is not sufficient. The admission must, in addition, contain a statement to the effect that the employee committed some form of misconduct against the employer for which compensation is payable.

The Adjudicator observed in the case of PM De Kock v Compass Group Southern Africa Pension Fund PFA/MP/00002506/2013) that the legislature did not intend to extend the provision of the Act to contractual disputes, as a result, the adjudicator found that the damages suffered by the respondents is not a damage as envisaged in section $37 \mathrm{D}(1)$ (b)(ii) of the Act. Consequently, the complainant's pension benefits can neither be withheld nor deducted and is entitled to payment of his pension benefits.

It becomes evident from the De Kock case that negligent conduct is insufficient for the purpose of section 37D (1)(b)(ii). This was also confirmed In Razlog v PLJ Pension Fund [2003] 1 BPLR 4294 (PFA). where the fund was unable to show that the complainant's mistaken dealings were in any way tainted with impropriety or dishonesty that the Adjudicator found that the fund was not entitled to make the deduction in spite of it being clear that the complainant had caused substantial loss to his employer.

\section{Insights from the Case of Highveld Steel and Vanadium Corporation Ltd v Ooshuizen [2009] 2 All 225 (SCA)}

The Court in the landmark case of Highveld Steel and Vanadium Corporation Ltd v Ooshuizen was tasked to determine whether or not the boards of the Funds had the power to withhold payment of pension benefits due to the member pending the outcome of a damages action instituted by the employer against a member. In this matter Oosthuizen commenced employment with the Highveld Steel as an observer in its metallurgical division and joined the Funds on 1 August 1978. In January 2006, Oosthuizen was promoted to hold the position of Unit Manager in charge of stores with contents worth approximately R177m at any given time. However on the 31 January 2007, Highveld Steel instituted disciplinary proceedings against Oosthuizen for bribery, fraud, theft and other transgressions involving dishonesty. The latter pleaded guilty to some of the charges. At the conclusion of the proceedings, on 16 February 2007, he was dismissed.

Shortly thereafter, Oosthuizen sought to withdraw his pension benefits from the Funds. On 28 February 2007, at the behest of Highveld Steel, which intended to institute an action against the Oosthuizen to recover losses it allegedly suffered as a result of his misconduct, the Funds resolved not to pay the benefits due to the latter pending the final determination of the contemplated action which was subsequently duly instituted.

Oosthuizen brought an application for an order directing the Funds to pay him his pension benefits. The Funds elected to abide the court's decision, despite initial opposition to the application. Highveld Steel then launched the application to intervene in the application and sought an interdict restraining the Oosthuizen from withdrawing any of his pension benefits and other relief. 


\subsection{The decision of the court}

The Court reiterated that the object of section $37 \mathrm{D}(1)(\mathrm{b})$ is to protect the employer's right to pursue the recovery of money misappropriated by its employees. The court emphasized that this object was also highlighted in the case of Twigg $\mathrm{v}$ Orion Money Purchase Pension Fund (1) [2001] 12 BPLR 2870 (PFA) at paragraph 21, Charlton v Tongaat-Hulett Pension Fund [2006] 2 BPLR 94 (D) at 97I-98B.

Maya JA confirmed at paragraph 19 that the powers for a fund to withhold a benefit are implied in section $37 D(1)(b)$ when he stated that: "such an interpretation would render the protection afforded to the employer by s37D(1)(b) meaningless, a result which plainly cannot have been intended by the legislature. It seems to me that to give effect to the manifest purpose of the section, its wording must be interpreted purposively to include the power to withhold payment of a member's pension benefits pending the determination or acknowledgement of such member's liability. The Funds therefore had the discretion to withhold payment of the respondent's pension benefit in the circumstances. I dare say that such discretion was properly exercised in view of the glaring absence of any serious challenge to the appellant's detailed allegations of dishonesty against the respondent."

However, the Court observed that there is a practical problem that threatens the efficacy of the remedy afforded by the section. In this respect, the Court substantiated that in many case employers only suspect dishonesty on the date of termination of an employee's service and fund membership with the consequence that pension benefits are paid before the suspected dishonesty can be properly investigated. It was further observed that, it has to be accepted as a matter of logic that it is only in a few cases that an employer will have obtained a judgment against its employee by the time the latter's employment is terminated because of the lengthy delays in finalizing cases in the justice system. The result, therefore, is that an employer will find it difficult to enforce an award made in its favour by the time judgment is obtained against him.

\section{Conclusions and Recommendations}

The recent determinations by the Pension Funds Adjudicator confirm that the Fund has powers to withhold pension benefits. The decision in Highveld is welcomed as it has put clarity to the uncertainty in the Pension industry as to whether a Fund was entitled to withhold payment, especially where there had been no written admission of liability by a member to an employer or where an employer had not yet obtained judgment against the employee. Indeed withholding pension benefits are in accordance with the Act provided that the employer complies with the requirements of the Act.

It is axiomatic that withholding pension benefits is a nightmare to pension fund members as delay in payment can go up to two years. In the process the pension fund members are in a limbo as they cannot access their benefits, consequently they must find other means of survival pending finalization of the pending cases. On the other side of the coin, employers cannot withhold pension benefits for any loss that result from employer-employee agreement. This also puts employers in a limbo pending finalization of the civil suits and it is a possibility that upon finalization of the civil suits the employee would not have any money to compensate the employer. The worst case scenario is that when an employee is convicted under criminal charges there would not be much for the employer to salvage.

It is recommended that there should be more training for trustees of the Fund so as to know exactly when Pension benefits can be withheld in terms of the Act. Further training is required for employers so as to enable them to know the other legal process that they can exercise in the event that their request to withhold pension benefits does not fall under section 37D of the Act.

\section{References}

Bendix S 2010. Industrial relations in South Africa. Cape Town, South Africa: Juta and Co Ltd.

Bendix S 2010. Labour Relations in Practice: An Outcomes-based Approach. Cape Town, South Africa: Juta and Co Ltd.

Blount EC 2010. Occupational crime: Deterrence, investigation, and reporting in compliance with federal guidelines. Florida, USA:CRC Press.

Jeram N, Shrosbree L 2005. Introduction to South Africa Pension Law Manual (unpublished), p.89.

Kruger P 2014. Withholding of Pension withdrawal benefits. From http://www.moonstone.co.za/withholding-of -pension-withdrawalbenefits/. (Retrieved on 25 June, 2014).

Malindi J 2012. Employers may withhold pension benefits if an employee has acted. From http://www.bowman.co.za/NewsBlog/Blog/Employers-may-withhold-pension-benefits-for-fraudulently-employee. (Retrieved on 21 June, 2014).

Nunoo NO 2013. An evaluation of the old and new pension schemes in Ghana and their effects on the informal sector. From http://air.ashesi.edu.gh/handle/123456789/112. (Retrieved on 16 March, 2014). 
Queen SM 2013. Withholding of pension funds benefits under the South African Law. From http://ul.netd.ac.za/handle/10386/1027. (Retrieved on 22 June, 2014).

Wells JT 2011. Corporate fraud handbook: Prevention and detection. New Jersey, USA: John Wiley \& Sons. 